\title{
Commodity, Sign, and Spectacle: Retracing Baudrillard's Hyperreality
}

Daryl Y. Mendoza

\section{Introduction}

The explicit expression of the reality problematic in Jean Baudrillard was first mentioned in his monumental 1976 work "Symbolic Exchange and Death" 1 and was further elucidated in an essay published a few years later entitled "Precession of Simulacra." I I is in these two works where Baudrillard argues how contemporary culture and society has come to the point in which the real has disappeared and is replaced by models "more real than the real." The thesis surrounding this diagnosis of current condition is what he calls Hyperreality.

At the onset, the aim of this paper is not to present an in-depth exposition of Hyperreality but rather to present its possibility. Though there maybe instances in which this paper will be able to present some fragments on Hyperreality but this serves only as corollaries to the elucidation of its possibility.

The manner in which this paper will proceed is through a rough retracing of the possibility of Hyperreality in the works that preceded both "Symbolic Exchange and Death" and "The Precession of Simulacra" since it is in these earlier works of Baudrillard that prefigured the path towards the reality problematic. Through examining certain works before 1976, what this paper will give are lampposts that will hopefully help navigate the introduction of Hyperreality in Baudrillard's work.

This paper will therefore show that the reality problematic inaugurated in "Symbolic Exchange and Death" should be understood in its relation, both as a continuity and break, to the general concern of his neo-marxist phase, ${ }^{3}$ i.e., the Marxist problematic of the commodity as the organizing principle of

1 This was first published in France in 1976. Cf. Jean Baudrillard, "L' échange symbolique et la mort" (Paris: Éditions Gallimard, 1976). For the English translation cf. Jean Baudrillard, "Symbolic Exchange and Death" trans. by Iain Hamilton Grant and Intro. Mike Gane (London: Sage, 1993).

2 This is the first essay in Baudrillard's "Simulacra and Simulation" which was first published in France in 1981, cf. Jean Baudrillard, "Simulacres et simulation" (Paris: Éditions Galilée, 1981). For the English translation cf. Jean Baudrillard, "Simulacra and Simulation" trans. by Sheila Faria Glaser (Michigan: University of Michigan Press, 2004).

3 This phase may have spanned the works from "The Systems of Object" and culminating with "The Mirror of Production." 
society, only this time, analyzed from the standpoint of semiology or what Baudrillard calls "semio-linguistics," pioneered by de Saussure and elaborated by Barthes. ${ }^{4}$ This paper will further present that Baudrillard's attempt to become more radical than Marx in analyzing the commodity has paved way for certain subversions, i.e., Baudrillard's reversals of dominant-dominated binary opposites: Production and Consumption, Use-value and Exchange value, Basestructure and Super-structure, which are located within Marx's critical discourse. These reversals lead to the saturation of Marx's very critique and through this illuminates a new problem which cannot be grasped by its own logic. It is this very obsolescence, exhausted out of Marx, that leads the path from the commodity to the reality problematic $-\mathrm{a}$ new problematic that requires a new analytic. But clearly, without the exhaustion of Marx and the commodity problematic, Hyperreality will not be possible. It is from this retracing, that this paper hopes to shed light to the very possibility of Hyperreality from the Marxist discovery of the Commodity form, to de Saussure's Conception of the Sign and to the Spectacle brought to fore by the Situationists and finally to Baudrillard's Hyperreality, the pathos of a society that has gone beyond alienation.

\section{Production, Consumption, and the Commodity Problematic}

Baudrillard's concern in his earlier books, particularly "The System of Objects"5, "The Consumer Society"6, and "For a Critique of the Political Economy of the Sign" role in society and culture. This commodity problematic retraceable back to Marx's general thesis in "Capital" argues that the underlying logic of capitalist societies is the accumulation of wealth through "immense collection of commodities" in which "the individual commodity appears as its elementary form." 8

Baudrillard, though liberated from the 19th Century Industrial confines of which Marx was in, and contextualized in the post-world war II era

${ }^{4}$ Barthes, coming from de Saussure's structural linguistics, liberates the Sign inherent within de Saussure's close-system to encompass not merely linguistic forms but also social and cultural forms in general. He presents this in his pioneering works on semiology and culture, from fashion to popular culture. Cf. Roland Barthes, "The Fashion System" trans. by Mathew Ward and Richard Howard (USA: University of California Press, 1983). and Roland Barthes, "Mythologies" trans. by Annette Lavers" (London, Paladin, 1972). This form of semiology, i.e., the application of the sign system to culture, outside the close-system of de Saussure, exerted tremendous influence on Baudrillard's overall work. Thus he is indebted to Barthes for his pioneering analysis of the Sign in culture. Verso, 1996)

5 Jean Baudrillard, "The Systems of Objects" trans. by James Benedict (London:

6 Jean Baudrillard, "The Consumer Society: Myth and Structure" trans. by Chris Turner (London: Sage, 1998).

7 Jean Baudrillard, "For a Critique of the Political Economy of the Sign" trans. and intro. by Charles Levin (USA: Telos, 1981).

8 Karl Marx, "Capital" Vol I. trans. by Ben Fowkes and Intro. Ernest Mandel (London: Penguin, 1990), 125. 
where advances in science and technology, has paved way for newer forms of analysis to the commodity problematic, follows this problematic particularly in the field of communication. Coming from this, Baudrillard's analysis still follows the central problem of commodity as "the structural problem of all societies" but it anticipates the importance of the role of communication in the analysis of the commodity. Thus, Baudrillard's analysis of the commodity form looks at the problematic in the lens of "semio-lingusitics" anticipating the importance of communication in the analysis of social phenomenon which Marx was unable to do. Baudrillard supplements Marxist analysis of society with de Saussure and Barthes' semiology. This is because as Baudrillard reexamines Marx, he found that the latter was unable to grasp a more elementary form than the commodity. Although it is "the structural problem of all societies"10 it is according to Baudrillard not the most radical. In paraphrasing Mcluhan, he contends that:

Marx, in his materialist analysis of production, had virtually circumscribed productive forces as a privileged domain from which language, signs, and communication in general found themselves excluded. In fact, Marx does not even provide for a genuine theory of railroads as "media," as modes of communication: they hardly enter into consideration. ${ }^{11}$

Thus, with this supplementation, Baudrillard analyzes the commodity from a more radical perspective, to consider it not merely as a material object but as a vehicle of communication, a Sign. In doing so, he found it necessary to invert certain dominant assumptions in Marx. For instance, the privileged status accorded by Marx on production, arguing that the production of material life is "the first premise of all human existence, and therefore of all history," which in turn gained Marx the title of being a "historical materialist" because for him, "The first historical act is thus the production of the means to satisfy these needs, the production of material life itself." 12

This privileging of Production for Marx also serves as a primary starting point that later will ground his interpretations of the world and his critique of the capitalist society. Baudrillard however inverses this analysis and argues that the analysis of the commodity in contemporary societies should no longer be based on production but rather it should be positioned to its opposite, i.e., consumption. According to him, consumption is not merely the

9 Gyorgy Lukacs, History and Class Consciousness, trans. by Rodney Livingstone (Cambridge, Mass: MIT Press, 1971), 83, cited in Baudrillard, "Critique of the Political Economy of the Sign," 5.

${ }^{10}$ Ibid.

11 Marshall Mcluhan, "War and Peace in the Global Village" (New York, 1968), 5. Cited in Baudrillard, "For A Critique of the Political Economy of the Sign," 164.

12 Karl Marx, "The German Ideology" ed. and intro. R. Pascal (New York: International Publishers, 1947), 16. 
passive recipient of production ${ }^{13}$ through satiation of needs but rather it is an active endeavor in "the manipulation of signs"14 towards the creation of the "person" and its integration within the system. The relationship between the subject which consumes and the object being consumed is what he calls "personalization."15 It is the objectification of the subject and the subjectification of the object. ${ }^{16}$ Consumption acquires for the person Signs in the object being consumed which in turn determines his status in society. In his "Systems of Objects" and "The Consumer Society" he elucidates in length how consumption creates and determines a person's identity within a capitalist society. In a section of the former, he shows how man, the interior-designer, manipulates signs in domestic space to reflect his subject. He arranges the objects according to "function", or its "ability to be integrated into a system, ${ }^{17}$ " thus "color, form and so on- no longer have any value of their own, but merely a universal value of signs. The order of Nature is everywhere present in the system, but present only as signs."18 For instance, the seemingly trivial choice between natural or synthetic décor and its arrangement within domestic space already speaks of a "cultural ideology analogous to that of the aristocratic myth itself in the social world" 19 specifically on how "warmth" is signified: synthetic wood or natural wood thus, synthetic warmth or natural warmth. The former speaks of a lack of "time," the absence of a history of wealth, while the latter speaks in a form of an "aristocratic" ideology, the wealth to acquire natural wood, to burn and to waste as opposite to the former. In the same form of analysis Baudrillard approaches the car-object in a psychoanalytic of its sign, he argues that:

depending on the way it is used and its particular features (from the racing 'spider' to the luxurious limousine), the motorcar may equally be well invested either with the meaning of power or with the meaning of refuge: it may be a projectile or a dwelling- place. But basically, like all functional mechanical objects, it is experienced - and by everyone, men, women and children - as a phallus, as an object of manipulation, care and fascination. The car is a

13 Thus, according to Baudrillard: "Consumption is surely not that passive process of absorption and appropriation which is contrasted to the supposedly active mode of production." Baudrillard, "Systems of Objects," 217.

14 "...consumption is the virtual totality of all objects and messages ready-constituted as a more or less coherent discourse. If it has any meaning at all consumption means an activity consisting of the systematic manipulation of signs." Ibid., 218.

15 Ibid., 5.

16 This is unlike the Marxist paradigm where the species-being (Gatungswessen) of man, the meaning of a human person is related and derived to his production while Baudrillard argues the opposite; the meaning of a human person is derived through what he consumes. This is his concept of "personification."

17 Baudrillard, "System of Objects," 67.

18 Ibid., 68.

19 Ibid., 39. 
projection both phallic and narcissistic, a force transfixed by its own image. ${ }^{20}$

The point is that the consumption of décor or of a car, the consumption of a commodity in general, is not consumption based upon a need, which in Marx is formalized as the Use-value. It is a consumption of what it signifies and how the consumer consuming the sign is integrated within the system. This is why, in the anticipation of communication as an important perspective in analyzing society, Baudrillard necessitates this inversal of priority, from the original conception of Marx on production to consumption.

Coming from this transference of importance in the productionconsumption spectrum, a corollary appears. In having presented the necessity of the sign process within the Marxist framework, Baudrillard went further to elaborate on the value founded upon the introduction of the sign process within Marx's analysis which is linked with the importance already accorded to consumption. He calls this value, the Sign-value, and it is this value that is central to his notion of Consumption for it is "the stage where the commodity is immediately produced as a sign, as a sign-value and where signs are produced as commodities." 21 As the sign-value is introduced and the marriage between semiology and Marxism is further elaborated, we are again in the juncture in which Baudrillard inverses two related concepts within Marx's philosophy: the use-value and exchange-value. It is from this inversion that the role of the sign-value interlinked with consumption is better elucidated.

\section{Beyond the Use and Exchange Value: The Myth of Needs and the Reign of the Sign}

When Marx bifurcated needs into primary and secondary needs, the former is premised on an "anthropological minimum" while the latter is founded on the "post-survival threshold." From this he is able to cement the concept of the Use-Value. Because the Use-Value is subjective, ${ }^{22}$ it therefore requires a value that is objective that standardizes the utility of an object. (This object may be useful for you, but this is junk to me.) In order to find a standard value for exchange, Marx introduces the Exchange-Value. The exchange - value is merely secondary to the use-value for the former merely standardizes the latter, since the latter is already inherent in the object. The exchange-value is the appearance, the "socially recognized standards of measurement for the quantities of these useful objects." 23 But according to Baudrillard, this form of analysis in our contemporary society no longer follows. He argues that the core of which a commodity's value is determined is

20 Ibid., 74

21 Baudrillard, "For a Critique of the Political Economy of the Sign," 147.

${ }^{22}$ It is dependent upon the person's need hence, it is merely "dangling in mid-air" Marx states it as: The usefulness of a thing makes it use-value. But this usefulness does not dangle in mid-air. Cf. Karl Marx, "Capital,” 126.

22 Ibid., 125. 
not by the use-value or the value in which a subject satiates a need, but by the exchange-value. In here, he again subverts two conceptually related terms in Marx. He argues that there is really no more "objective" value of a commodity because the exchange-value only uses the use-value, as a mere alibi for its existence. The exchange-value uses the use-value as a legitimizing factor that initiates the exchange process. This reduction of the use-value as an imaginary excuse for the exchange-value has rendered it as a value that is non-objective and use-less.

How is this so? The use-value operates on the assumption of need. Precisely because an object is needed then it is accrued with a use-value. But according to Baudrillard, needs and everything that possesses a use-value only occurs within a system of exchange since the use-value cannot be realized without its exchange-value. Within this system of exchange, and coming from the importance of communication that Baudrillard earlier presented, the commodity therefore not merely possesses an exchange -value but a Sign value. ${ }^{24}$ Thus with the eclipse of use-value, exchange-value exchanges not just the inherent utility in objects but already what it signifies in a system of integration. This is the value that Baudrillard supplemented in the analysis of society. Thus, primary needs, which possess the premise of an "anthropological minimum" according to Baudrillard is merely a myth, and that needs are always secondary since a primary need is a concept organized to ground the system of exchange, similar to the Signified in the semiotic process. ${ }^{25}$ But here we witness a spiral, Baudrillard cites Marx in saying that: "Production not only produces goods; it produces people to consume them, and the corresponding needs." Thus, when one "needs" he has to enter the realm of the social, and when he enters he does not only exchange a commodity, but also language, concepts and signs. In this realm, primary and secondary needs blur, so far as I want to "eat" to satiate my hunger, I may chose not to, or I may choose to do so, ${ }^{26}$ and

24 The Sign-Value, is that value which loads a commodity with a sign of prestige. As Use-Value is that utility, exchange-value that of Equivalence, the Sign-value is that of difference. By consuming a sign-value one is able to differentiate oneself from another.

25 As Marx's description of the system of exchange is possible only when there is the use-value, de Saussure's semiological process is only possible when there is the signified, both being essential points to their respective systems.

26 Baudrillard even notes that in psychoanalysis, eating, is a form of compensation for the lack of love And how this is acted upon is mediated by signs in the system. In the $6^{\text {th }}$ footnote to "The Ideological Genesis of Needs" he states: "But it is well known that eating can satisfy an oral drive, being a neurotic substitute for lack of love. In this second function, eating ,smoking, collecting objects, obsessive memorization can all be equivalent... Desires, on the other hand, is signified throughout an entire chain of signifiers. And when it happens to be a desire for something experienced as lost, when it is a lack, an absence on which the objects that signify it have come to be inscribed, does it make any sense to treat such objects literally, as if they were merely what they are? And what can the notion of need possibly refer to, in these circumstances?" cf. Baudrillard, "Critique of the Political Economy of the Sign,"69. In interpreting Baudrillard, Pawlett reechoes the statement in that: "Drives such as aggressiveness and erotic cravings, are processed through signs. Increasingly sexual and aggressive drives are promoted by the consumer system; we are encourage to realize our desires, to indulge our cravings." Cited in William Pawlett (January 2008) "Against Banality- The Object System, the Sign System and the Consumption System," in International Journal of Baudrillard Studies Vol. 5, 
if I do so I have to face the tyranny of choice, or what Baudrillard calls "discretionary income"27, one chooses what to consume in which the limitation is income. In contemporary society, one could no longer consume the foodcommodity in its raw sense, one always consume its sign-value inherent in the commodity as it is exchanged in the current system. Hence, when one chooses a restaurant, it is hardly a choice governed by need in the context of survival, it is a choice prompted by the spectacle of the image and the limitation of income.

To choose between fast-food over five-star dining, between Chinese or French cuisine is a choice for signification rather than a choice for survival. Another example would be Bread. There is no such thing as a generic loaf of bread, not even homemade bread is generic in a sense since the ingredients, the qualities, the brands, the labels, that it takes to create the bread, is loaded with Signs. Signs are interchange in society, anything up for exchange, also possesses this Sign-value. The raw object is nowhere to be found; the raw object which is ideally what the primary need correspond to is blurred with the presence and ubiquity of the Sign in our times. Baudrillard even asks: "Is loss of status- or social non-existence less upsetting than hunger?"28

With this, needs become problematic in the political economy. There is no such thing as an "anthropological minimum" this premise was only created as an ideology by the System as to convince man of a primary need, which in turn convinces him of a secondary need that crosses what the primary needs encapsulate; the drive for meaning, in which meaning is found in consumption. He writes:

Even before survival has been assured, every group or individual experiences a vital pressure to produce themselves meaningfully in a system of exchange and relationships. Concurrently, with the production of goods, there is a push to elaborate significations, meaning with the result that the one-for-the-other exists before the one and the other exist themselves. Thus, the there could be a million possible motivation of one's consumption of a certain good, but what lies underneath is always a meaning. This meaning does not exist in the relation of the subject and the object in rational ends (needs) but in difference and signification. One's difference from another person through his consumption of objects loaded with signification that determines difference. ${ }^{29}$

No.1 available from: <http://www.ubishops.ca/BaudrillardStudies/vol5 1/pf/v5-1-article13Pawlett_pf.html $>$ January 2, 2010 .

${ }^{27}$ Discretionary Income, is an income derived by Capital, allowing you to choose what to consume with it. Cf. Baudrillard,"For a Critique of a Political Economy of the Sign," 81.

28 Ibid., 81 .

${ }^{29}$ Baudrillard, For a Critique, 74-75. 
Baudrillard's radical analysis of Marx's critique of society through the supplementation of semio-linguistics, has introduced the importance of the Sign in political economy. As the sign-value begins to overshadow both exchange-value and use-value, so do all commodities become an Image. For Baudrillard, as signs proliferate, needs no longer arise from objective and stable origins as objects transmuted to signs become Ideological. Baudrillard states that: "needs could no longer be defined in the naturalist-idealist thesis (need as objective and rational) rather they are defined as function induced by the internal logic of the system - there are only needs because the system needs them" 30

This last statement necessitates a revisiting of Marx's moment of inverting his Master to stand on his feet, his theory of the Base Structure and Super Structure. How could the concept of needs be ideological if need is located as an assumption in the Base Structure and ideology in the Marxist conception as "false-consciousness" is located in the Superstructure? Here, Baudrillard once again radicalizes Marx's analysis, and presents how this spectrum, the material life and Consciousness, is de-leveled. In this stage, the reality problematic in Baudrillard slowly crystallizes, to replace the commodity paradigm that serves as the theme in his earlier analysis of society.

\section{Ideology and the Spiral: The Spectacle and Beyond}

With the proliferation of Sign in society, the political economy stands on the stage where the commodity's sign-value serves as the basis for the analysis of political economy. It is in this juncture that signs and images slowly reduce reality into appearance. For the Situationists, this is exactly what they call "The Society of the Spectacle." When Marx formulated the development and abstraction of the exchange-value in his "Capital", he presented its progress from "simple-isolated" towards a general form of exchange which, as he would conclude, is with money. ${ }^{31}$ Contemporary society however has done greater progress in the abstraction of the exchange form when it introduced Credit cards and the Stock exchange, to name a few, in society. ${ }^{32}$ Unlike money which is still subjected to foreign exchange rates, Credit cards, a form higher than money in terms of abstraction, surpasses the foreign exchange, i.e., it is capable of exchanging in any foreign currency unlike money which has yet to be further transmuted to a specific currency to realize its power to exchange. This complexification of the abstraction of the exchange form also accentuates its status from a material objects towards pure image. In history, when 1 coat was equivalent to 20 yards of linen, to its more general form in which 1 coat or

30 Baudrillard, For A Critique, 82

${ }^{31}$ Cf. Marx, "Capital," 139-163.

32 The abstraction of the commodity form and its relation to Debord and Baudrillard echoes the discussion made by Steven best. Cf. Steven Best, "The Commodification of Reality and the Reality of Commodification: Baudrillard, Debord and Postmodern Theory" in Baudrillard: A Critical Reader, ed. Douglas Kellner (UK: Blackwell, 1994), 41-67. 
20 yards of linen or $10 \mathrm{lb}$ of tea is equivalent to 2 ounces of gold $^{33}$ the exchange form is still an object - money in a concrete form. In contemporary society however, it has gone beyond its concrete form, it has become an image, exchange form as digitality. With this general form of exchange, the economic mode of production signified by pure image has become transparent with the images and spectacles of social life. This coalescence of economy and culture becomes the commodification of Society as a whole. Hence, Debord writes: "In societies where modern conditions of production prevail, all of life presents itself as an immense accumulation of spectacles. Everything that was directly lived has moved away into a representation." ${ }^{34}$ Political economy now revolves around images as the form of exchange in commodities - the relationship between the consumer and commodity is mediated with the image or spectacle. The value of credit can be transmuted to anything in the society of Spectacle. Thus, the "universalization of the commodity form is seen to be the reduction of reality to appearance... commodification." 35 So, capital is not merely the mirror which is reflected to society, but that capital becomes immanent in social life, the general form of exchange has become culture itself. Debord writes: "The Spectacle is capital to such a degree of accumulation that it becomes an image. ${ }^{36}$ Thus, the mode of production and the social consciousness bombarded with images, amplified by Mass Media, becomes a relationship of spectacle. Society has transformed the relationships of subjects to objects, and subjects to other subjects, into a relationship based on what can be shown - appearances, between brand names and labels. For Debord: "what appears is good; what is good appears",37 The consumer society as Baudrillard thought of, is consonant to Debord's society of spectacle.

Baudrillard, heavily influenced by the Situationists, comes from this analysis. Even as early as "The System of Objects," he already wrote on the significance of the spectacle of the image in commodities through advertisements. He writes:

We consume the product through the product itself, but we consume its meaning through advertising. Picture for a moment our modern cities stripped of all signs, their walls blank as an empty consciousness. And imagine that all of a sudden the single word GARAP appears everywhere, written on every wall. A pure signifier, having no referent, signifying only itself, it is read, discussed, interpreted in a vacuum, signified despite itself - in short, consumed qua sign. .. Advertising's true referent is here

${ }^{33}$ Ibid., 162.

34 Guy Debord, "The Society of the Spectacle" trans. by Ken Knabb (London: Aldgate Press), thesis 1, 7.

35 Best,. "The Commodification of Reality and the Reality of Commodification: Baudrillard, Debord and Postmodern Theory," 50.

36 Debord, "The Society of Spectacle," thesis 34, 17.

${ }^{37}$ Ibid., thesis 12, 9. 


\section{COMMODITY, SIGN, AND SPECTACLE}

apparent in its purest form: like GARAP, advertising is mass society itself, using systematic, arbitrary signs to arouse emotions and mobilize consciousness, and reconstituting its collective nature in this very process. ${ }^{38}$

This reduction of the world into signs being exchange with each other, and the hyperbolic image as the spectacle, forms the sign mediated-relationship between subject and object. This relationship however being mere appearance is an illusion. The Spectacle is an illusion of the real world of oppression and exploitation of the system itself. At least for Debord, the spectacle is a part of how the entire political economy works, as considered by Marx. It is a progression of Marxist analysis and thus still holds that the appearances in culture are veils of the real world of estrangement. The Situationists continues to follow the logic of a structural Marx in which social consciousness is determined by material life.

Revisiting Marx's theory of Infrastructure and Superstructure, he argues that those who control the mode of production are able to shape social consciousness; the ruling ideas are propagated, maintained, and originates from the ruling class, who clings to their class interest, in order to maintain the status quo. Thus:

The ideas of the ruling class are in every epoch the ruling ideas: i.e., the class which is the ruling material force of society is at the same time its ruling intellectual force. The class which has the means of material production at its disposal, consequently also controls the means of mental production, so that the ideas of those who lack the means of mental production are on the whole subject to it. The ruling ideas are nothing more than the ideal expression of the dominant material relations, the dominant material relations grasped as ideas; hence of the relations which make the one class the ruling one, therefore, the ideas of its dominance. ${ }^{39}$

He further argues that "the phantoms formed in the human brain are also, necessarily, sublimates of their material life-process, which is empirically verifiable and bound to material premises. Morality, religion, metaphysics, all the rest of ideology and their corresponding forms of consciousness, thus no

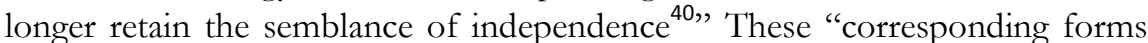
of consciousness", these ideas is what Marx call, Ideology. Ideology here is a pejorative to its original conceptions by de Tracy, ${ }^{41}$ in that, ideologies are

38 Baudrillard, "Systems of Object," 198.

39 Karl Marx, "The German Ideology," 39.

40 Ibid., 14.

${ }^{41}$ Destutt de Tracy was the first to give the term ideologue in 1796 , which refers to a "science of ideas." 
products of the system itself propagated to insinuate its survival, and its survival is dependent upon class antagonism and the establishment of the status quo. Ideology is a necessary illusion, or "false consciousness" that masks the original state of life in society. As, Louis Althusser, defined to us succinctly, Ideology is a "representation" of the imaginary relationship of individuals to their real conditions of existence" 42 Ideology, by being a misrepresentation propagates the illusion that there is no alienation occurring in the system. This veil of illusion allows for the system to continually function, sedating the laborers from realizing their present miserable condition and their possibility of emancipation. Debord, like Althusser, believes that the spectacle is an illusion, a "false consciousness." By raising the commodity into a more abstract form, it has for Debord become an image, accentuated, a spectacle. And yet for him, it is still located properly within the political economy. For, Debord and Structural Marxists like Althusser, there is still the optimism for liberation from "false consciousness" to reality. But according to Baudrillard, this is fiction. It is in here where Baudrillard, although coming from the analysis of the Situationists, also break away from. He radicalizes the Situationist's analysis of society.

Baudrillard argues that the sign-form, the image, which at first through analysis- stems from economic-exchange, cannot merely be enframed so long within the cage of political economy. As signs, it transmutes everything into signs, i.e., as soon as an object is conceived as a sign it extends itself to other objects, it signifies other objects and therefore rendering them also as signs. The very conception of the Sign, particularly the Signifier, initiates a semiotic process that affects the entire structure of society and culture. Everything is reduced to sign. This is precipitated by modern forms of Mass communication and the commodification of culture.

In this mad propagation, signification can no longer retrace itself merely as a product of the mode of production in Marx, for according to Baudrillard, even the mode of production is merely a sign of something else. Perhaps Baudrillard's analysis of this point in which the signifier could no longer locate its signified can be owed to Derrida's earlier lecture on the scandal in the "history of structure." 43 As Derrida presented a rupture in Structure, particularly in Levi-Strauss, so did Baudrillard with Marx. And such is why Baudrillard argues that Marx's analysis was not radical enough. If the

${ }^{42}$ Louis Althusser, Ideaology and Ideological State Apparatuses, in "A Critical and Cultural Theory Reader" ed. Anthony Easthope and Kate McGowan, (Buckingham: Open University Press, 1998), 52.

43 Derrida in his famous 1966 lecture in John Hopkins states: "Perhaps something has occurred in the history of the concept of structure that could be called an "event," if this loaded word did not entail a meaning which it is precisely the function of structural-or structuralistthought to reduce or to suspect. But let me use the term "event" anyway, employing it with caution and as if in quotation marks. In this sense, this event will have the exterior form of a rupture and a redoubling".Jacques Derrida, "Structures Signs and Play in the Human Sciences" in Writing and Difference, trans. by Alan Bass (London: Routledge, 1978), 278. 
very fundamental assumptions of Marx: "needs" "labour" and "production",44 are mere signs, then they can be reduced as ideological concepts created by the system itself to insinuate its survival. But this becomes the problem, for if the entire movement of material history, together with its critique, is grounded upon these key axiomatic concepts in the Marxist discourse which are merely sign's signifying other signs in an infinite exchange, then what then is the future of Material History? He writes:

in a work, man is not only qualitatively exploited as a productive force by the system of capitalist political economy. In the last instance, the system rationalizes its power here. And in this Marxism assists the cunning of capital. It convinces men that they are alienated by the sale of their labour power, thus censoring the much more radical hypothesis that they might be alienated as labor power, as the "inalienable" power of creating value by their labor. ${ }^{45}$

With this Marx, according to Baudrillard, tried to turn the order of Capital using its own ideological phantasms. Baudrillard argues that: Marx really "changed nothing basic: nothing regarding the idea of man producing himself in his infinite determination," 46 "Production, labor, value, everything through which an objective world emerges and through which man recognizes himself objectively - this is the imaginary ${ }^{\text {" }} 7$ The progress of the commodity form from its material beginnings towards both its radicalization, and the same time, its abstraction has led the entire structure of historical materialism to become "a giant simulation model" which the "dialectical' generalization of this concept is merely the ideological universalization of this system's postulates. ${ }^{, 48}$

At this point, production in Marx ceases. There is nothing more coming to be, no more production; everything is reproduced by the system ${ }^{49}$ as a sign. This is the juncture which Baudrillard calls the "End of production," when the distinction between the Super and Base structure collapses. And with it, the entire structure of Marxist discourse. The very concepts that grounds Political Economy as structure, begins to leave its own confines. Political Economy has become a model to the violence that it once propagated. There is

${ }_{44}$ Baudrillard presented a deconstruction of these important foundations of Marx's Historical Materialism in his work "The Mirror of Production." Cf. Jean Baudrillard, "The Mirror of Production," trans. by and intro. Mark Poster (USA: Telos Press, 1975).

${ }^{45}$ Jean Baudrillard, "Mirror of Production"), 31.

46 Ibid.,33.

47 Ibid.,19.

48 Ibid.,33.

${ }^{49}$ Even here, the term "system" no longer refers to that which has logic, a beginning and an end. This system is neither aleatory nor deterministic. In his later works, Baudrillard would talk about this in length. 
therefore no more Political Economy, in the sense that Marx imagined: no more labour, no more needs, no more production. Political economy here, and all its concepts, are reduced as simulations, that assure us of the reproduction of its violence in a "dialectical equilibrium." Political economy and its critical discourse once sought Nature as its "great referent", now it has become its own reference. From the "Revolution of the Law of Value", he writes:

From now on political economy is the real for us, which is to say precisely that it is the sign's referential, the horizon of a defunct order whose simulation preserves it in a 'dialectical' equilibrium. It is the real and therefore the imaginary, since here again the two formerly distinct categories have fused and drifted together..$^{50}$

Once, the mode of production was the hidden reality, and social consciousness, with ideology, its appearance. Now, ideology itself no longer knows what it hides. Social Consciousness is the Mode of Production. "Needs, "Labour" and "Production" these are no longer the reality that grounds the system; they are the imaginary that propagates the system. Earlier, Needs was presented to be mythical. While Labour, according to Baudrillard, "shines through non-labour," ${ }^{, 51}$ because through wages, the system buys back labour in non-labour, i.e., non-work is the venue to consume through wages. It returns back the capital that was expended and continues to circulate the spiral of income and expense, labour and play, re-production and consumption.

This is the point when the whole system short-circuits. The beginning was merely a phantasm, the reference is erased, and the end merely an illusion. ${ }^{52}$ For Baudrillard, already leaving the neo-marxist embrace, leaving behind the analysis of Debord and others, considers that any attempt to talk about emancipation or alienation will be futile, because the system itself is no longer grounded upon a "great signified", a presence, or the real - emancipated from what? Everything has become a circular play.

50 Baudrillard, "Symbolic Exchange and Death," 31.

${ }^{51}$ To think of the opposite of labor, which is play or non-labour, as an escape from the assembly line of Political Economy, is a lapse to illusion. He writes: "Although the concept of non-labor can thus be fantasized as the abolition of political economy, it is bound to fall back into the sphere of political economy as the sign, and only the sign of its abolition. It already escapes revolutionaries to enter into the programmatic field of the "new society." Cf. Baudrillard, "Mirror of Production," 41.

52 As a minimal note, Baudrillard in a later work joined the discussion on the "apocalyptic turn" of philosophy. He argues pass the eschatology of Fukuyama by presenting that before history can end, it disappeared. Coming from his analysis of systems in his earlier work, the book's thesis in a question may be posed: If the system is lost in its self-referentiality, Hyperreality, then how could it ever meet its telos? Thus he writes: " History will not come to an end - since the leftovers, all the leftovers - the Church, communism, ethnic group, conflicts, ideologies -are indefinitely recyclable... History has only wrenched itself from cyclical time to fall into the order of the recyclable" Cf. Baudrillard, "The Illusion of the End" trans. by Chris Turner (California: Stanford University Press, 1994), 27. 
At the beginning, Baudrillard supplemented communication within the Marxist framework in order to understand and diagnose the social condition of late capitalism. It is this very supplementation that has led him beyond Marx, beyond alienation and production. It has led him to the analysis that society, conceived radically through signs, implodes into a reality "more real than the real." This is Baudrillard's Hyperreality. Hence, he writes: "We no longer partake in the drama of alienation, but are in the ecstasy of communication." 53

Department of Philosophy, University of San Carlos, Philippines

\section{References}

Althusser, Louis, "Ideology and Ideological State Apparatuses," in A Critical and Cultural Theory Reader, ed. by Anthony Easthope and Kate McGowan (Buckingham: Open University Press, 1998).

Barthes, Roland, Mythologies, trans. by Annette Lavers (London: Paladin, 1972). , The Fashion System, trans. by Mathew Ward and Richard Howard (USA: University of California Press, 1983).

Baudrillard, Jean, For a Critique of the Political Economy of the Sign, trans. by Charles Levin (USA: Telos, 1981). 1975). Mirror of Production, trans. by Mark Poster (USA: Telos Press, Simulacra and Simulation, trans. by Sheila Faria Glaser (Michigan: University of Michigan Press, 2004). Symbolic Exchange and Death, trans. by Iain Hamilton Grant (London: Sage, 1993).

The Consumer Society: Myth and Structure, trans. by Chris Turner (London: Sage, 1998).

The Ecstacy of Communication, trans. by Bernard and Caroline Schutze, ed. by Sylvere Lotringer (USA: Semiotext(e) Foreign Agent Series, 1988).

The Illusion of the End, trans. by Chris Turner (California: Stanford University Press, 1994). 1996).

The Systems of Objects, trans. by James Benedict (London: Verso,

Debord, Guy, The Society of the Spectacle, trans. by Ken Knabb (London: Aldgate Press).

Derrida, Jacques, Writing and Difference, trans. by Alan Bass (London: Routledge, 1978).

Lukacs, Gyorgy, History and Class Consciousness, trans. by Rodney Livingstone (Cambridge, Mass: MIT Press, 1971).

McLuhan, Marshall, $W$ ar and Peace in the Global Village (New York, 1968).

53 Jean Baudrillard, "The Ecstasy of Communication" trans. by Bernard and Caroline Schutze, ed. Sylvere Lotringer (USA: Semiotext(e) Foreign Agent Series, 1988), 22. 
Marx, Karl, Capital, Vol I., trans. by Ben Fowkes and Introduced by Ernest Mandel (London: Penguin, 1990).

The German Ideology (New York: International Publishers, 1947).

Pawlett, William, "Against Banality- The Object System, the Sign System and the Consumption System," in International Journal of Baudrillard Studies, 5:1 (January 2008), < $\underline{\text { http://www.ubishops.ca/BaudrillardStudies }}$ Lvol5 1/pf/v5-1-article13-Pawlett pf.html $>$.

Steven Best, "The Commodification of Reality and the Reality of Commodification: Baudrillard, Debord and Postmodern Theory," in Baudrillard: A Critical Reader (UK: Blackwell, 1994). 